Tourism 2009, 19/1-2

\author{
Andrzej Matczak \\ Łódź University \\ Institut of Urban Geography and Tourism \\ matczak@geo.uni.lodz.pl
}

\title{
THE URBANIZATION OF SUMMER HOLIDAY ESTATES SURROUNDING ŁÓDŹ: WIŚNIOWA GÓRA
}

\begin{abstract}
The article presents the reconstruction of the urbanization process in Wiśniowa Góra, a village near Łódź. It came into being in 1870 as a farming village, surrounded by a forest. After several years the holiday function developed there, which became the base for the general development of the destination during the inter-war period. In 1945 - 1989 Wiśniowa Góra became a dormitory village and a summer holiday estate. The political and economic transformation, which started in 1989, has led to the collapse of the holiday function and the development of the residential function, thus transforming Wiśniowa Góra into a Łódź suburb.
\end{abstract}

Key words: urbanization, suburban village

Łódź and its surroundings are located on the main watershed in Poland dividing the Vistula and Odra basins, in the area of Łódź Uplands. In the past, the characteristic features of this watershed area included the limited availability of transport, low population and slow economic development. The development of Łódź, given municipal rights in the early $15^{\text {th }}$ c., was slow and based on farming and crafts, catering for the needs of neighbouring small, woodland settlements. For a long time, from the Middle Ages until the partitions of Poland, the development of settlements and the economy took place on the slopes of the Łódź Uplands, slowly entering the wooded watershed areas. The scarce population and the obvious retardation of socioeconomic development in this region were among the causes of Prussian colonization at the end of the $18^{\text {th }}$ c. Only in the early 19th $\mathrm{c}$. did Eódź, situated within the borders of Congress Kingdom, start to transform itself into a strong textile industry centre, which at the end of the $19^{\text {th }} \mathrm{c}$. had become the second industrial centre in Poland after Warsaw. This resulted in increased settlement around Łódź.

An example of such a settlement is Wiśniowa Góra. The reconstruction of the changes in its functional-spatial structure over a span of nearly 150 years, was based on the original source materials included by the author in his $\mathrm{PhD}$ thesis written in 1982 (MATCZAK 1982), as well as by PRYC (1962) and WILCZAK (1984) in their MA theses. The materials were collected during field study in July 2004, conducted with $2^{\text {nd }}$ year geography students of the
University of Łódź, as well as during surveys in which the author attempted to test the concept of the tourist area cycle using Wiśniowa Góra as his example (MATCZAK 2005).

Wiśniowa Góra is situated $14 \mathrm{~km}$ east of Łódź. After the railway connection between Łódź and Koluszki was opened in 1869, the accessibility of the new village was very good; the train took passengers to Andrzejów, and then it was 2-3 km to cover on foot or by droshky. At present, the railway connection has lost its significance as Wiśniowa Góra is easily accessible from Łódź by road. The village lies on the edge of a large forest.

The area of today's settlement was originally covered with a pine forest which only started to be felled in the second half of the 19th $\mathrm{c}$. Between 1879 and 1883 the parcelling and sale of land began. The plots were 2-10 morgas (2.8-14 acres) in size and intended for farming. They were bought by 66 settlers, who cut the forest themselves. The soil was very poor and the owner of the Bedon estate, who sold the land to the settlers, imposed certain restricttions: they could not run licensed restaurants or open shops, and they had to get their provisions from the manor shop and inn. They were not allowed to sell or divide the plots they had bought without permission from the manor. From the very beginning, there was no chance for Wiśniowa Góra to develop as a farming area and another economic basis had to be found for its development.

At the beginning of the $20^{\text {th }} \mathrm{c}$. the population of Łódź exceeded half a million and its inhabitants 


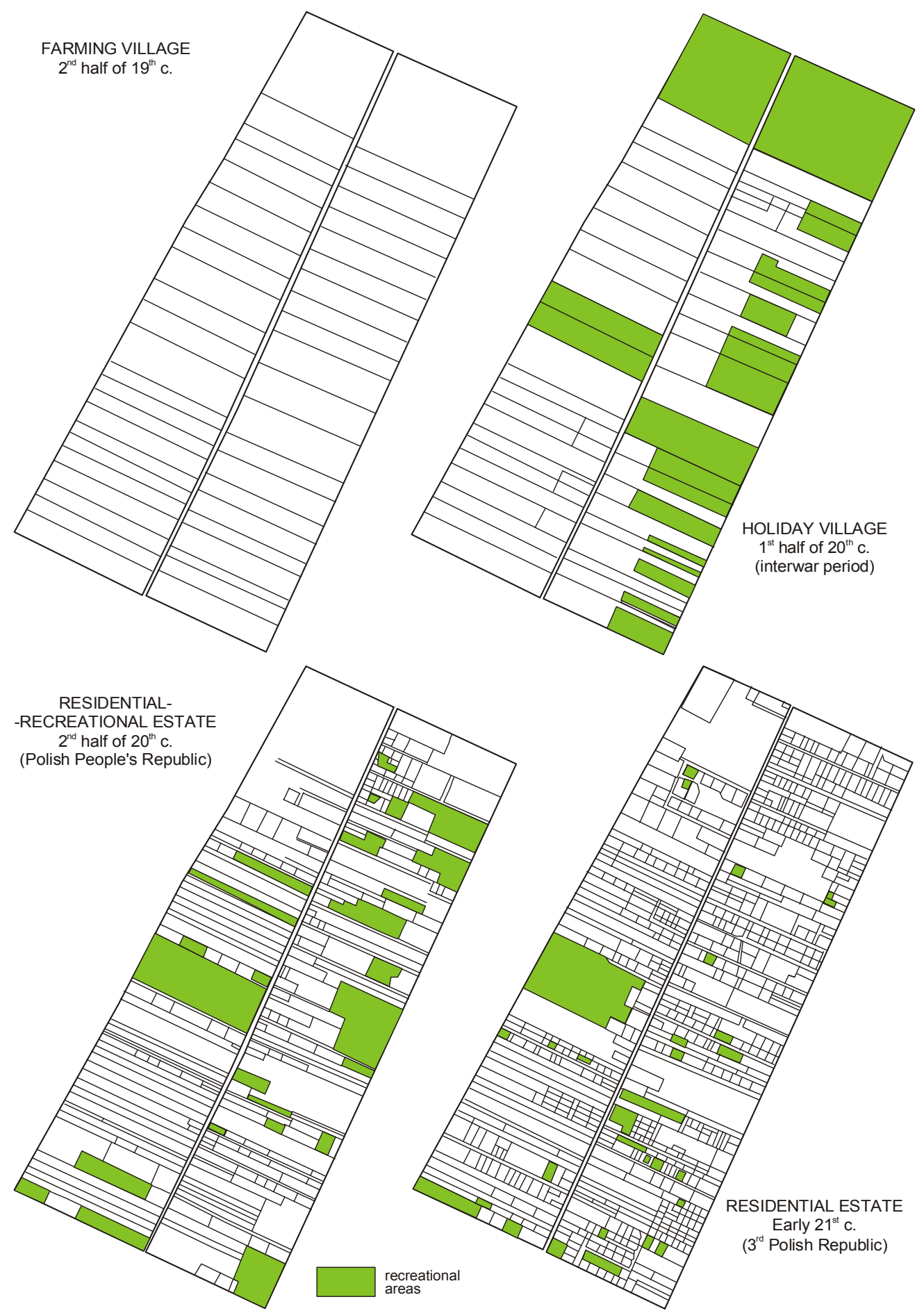

Fig. 1 Changes in the morphology (spatial system) of Wiśniowa Góra in 1870-2008; an illustration of the urbanization of a summer holiday estate (s o u r c e: author)

started to look for recreational areas near the city. These had to meet the following conditions: 1) be close to Łódź, 2) have good transport connection with Łódź, 3) which enabled the family breadwinner to work in the city (this mainly concerned craftsmen, merchants and clerks), 4) be situated next to a forest (pine forest in particular), and 5) be cheap as far as accommodation was concerned. Wiśniowa Góra met all these condition and in about 1900 a further sale of land began and the buyers included Jews. The holiday function began to develop but at first it was not organized, holidaymakers rented apartments for 
the summer from local peasant families, who moved into the farm buildings for that time. The number who organized their visit in the very favourable and healthy natural conditions was relatively small. They were not able to affect the lives of local inhabitants or the economy seriously. Only shortly before World War I, did more start to arrive and the local population began to benefit from serving them. In 1921 the number of local inhabitants reached 267, but including only 70 land owners. Further development of the holiday function there was limited by the restrictions mentioned before which were lifted only in 1928.

After 1928 some of the existing plots of land were sub-divided and sold and by the late 1930s the number of land owners had risen to 284. In the period of 1928-39 Wiśniowa Góra developed rapidly as a summer holiday village characterized by:

1) an organized form of recreation which took place in a number of pensions, rooms rented from local inhabitants and in privately owned accommodation,

2) an extended transport network (a train to Andrzejów and then one of 300 droshkies to Wiśniowa Góra; also a direct bus from Łódź to Wiśniowa Góra five times a day),

3) the gradual prolongation of the holiday season. At first it was only summer, which allowed wooden buildings, but as pensions started to be built of brick (nine) and were equipped with all modern conveniences, people could stay there all year round.

4) the development of tourist infrastructure: a swimming pool (built in 1934), cinema, café, shops (in 1939, 206 licences were issued to merchants, craftsmen and different kinds of service providers),

5) an increase in the number of holidaymakers to about 30000 annually (including 7000 of Łódźs Jews). This figure was several times higher than the local population,

6) services provided by local inhabitants for the holidaymakers who became one of the main income sources.

The development of the holiday function caused an internal spatial transformation of the village. Originally, Wiśniowa Góra was organized around a single street (Fig. 1) and the buildings were located along a section of the main road connecting Brzeziny with Tuszyn. The transformation of a farming village into a summer holiday estate brought a change to its physiognomy and morphology. The farmland was divided into summer plots parallel to the main road, with a preference for the north-eastern part located closer to Andrzejów (train station) and Andrespol, directly adjacent to a large forest and which included two thirds of the buildings and streets. Along Tuszyńska Street, the main road, buildings with residential and service functions were located (a feature preserved from the agricultural period), and at the back, especially in the eastern part buildings with recreational and residential functions could be found. The buildings in Wiśniowa Góra consisted of those constructed at the first stage of the formation of a farming rural village (one-storey houses, with 2-3 rooms, small windows, situated on the main street especially in its southern part), 2) buildings constructed at the period of village development, (villas and pensions, often multi-storey with many rooms, mostly wooden (3/4), but also brick (1/4), with characteristic annexes and large windows, letting in clean air and lots of sunshine). They were scattered all over Wiśniowa Góra, but the majority could be found in the eastern part, on side streets near the forest (there were almost none on Tuszyńska Street).

Further development of the holiday estate in Wiśniowa Góra was stopped by World War II. The local population was relocated to the neighbouring villages and their houses were taken over by the army and German families. Many buildings were demolished by the Germans. After the war some other buildings, whose owners did not return, were completely ran down. Many others were inhabited by those coming from the ruined districts of Łódź or repatriated from the eastern borderlands. In the first 25 years after the war registration restrictions in large cities (including Łódź) resulted in an inflow of people working in Łódź, but unable to settle there, to such estates, especially those with available accommodation. Wiśniowa Góra was one of them. Deserted villas and pensions were partly transformed into flats. Therefore, in 1946 Wiśniowa Góra had a population of 1135 and in 1960 - 2169. In this way a pre-war holiday estate had become a dormitory village (Fig. 2).

Wiśniowa Góra developed as a dormitory village very rapidly and in the 1960s it was clearly a dormitory estate of Łódź. An increase in population resulted from intensive migration. In the first years after World War II, inhabitants born before 1939 constituted only $6 \%$ of the population, the majority had arrived from Łódź (c. 45\%) and other places in Łódź Wojezództwo (42\%). At that time a considerable number (c. 5.5\%) were repatriates from the eastern borderland while a very small number (less than 1\%) came from other parts of Poland and abroad. In the early 1960s nearly half were of working age and almost three quarters had a permanent job, over $80 \%$ commuting to work to Łódź (c. 69\%) and to the places en route $(12.5 \%)$ which are now within the administrative borders of the city. Nearly 5\% travelled to the other local settlements and towns situated further away. In Wiśniowa Góra itself, 
employment was found by only $13.8 \%$ of the working inhabitants. The settlement was inhabited by relatively small families, mostly consisting of four members $(28.3 \%)$. The joint percentage of threemember $(15.4 \%)$ and two-member $(14.5 \%)$ families was $29.9 \%$, and of five-member families (19.8\%) and larger was $35.4 \%$. The development of the dormitory function turned many recreational buildings into residential ones and in the early 1960s nearly two thirds were residential. There were 167 of them, and they offered 519 flats with 1039 rooms, the most popular being one- and two-room flats (82\%). At that time $75 \%$ of the buildings were wooden and $25 \%$ of brick. They were solely one-storey (80\%) and twostorey buildings, fully electrified. The dormitory character was also reflected in the land use structure with the areas directly and indirectly related to housing covering a little over one quarter of the total area, and including orchards and gardens, over one third. niowa Góra. However, the majority of pensions which survived the war were passed over to Łódźs factories and turned into summer holiday centres for children. The recreational function was preserved, only the 'customers' changed and four to six thousand children spent their holidays in this way every year. Weekend recreation developed without major problems and an old swimming pool was rebuilt and equipped with new changing rooms, a café, pavilions, etc. During a summer weekend between 1000 and 1500 people a day arrived, while the children spending their holidays there were visited by their families at weekends. In the 1960s on a typical weekend day about 8000 people arrived by train alone, apart from those who travelled by bus or car. At the same time the building of private summer houses clearly lagged behind. After the war, despite some economic revival, there were only 50 plots and summer houses and the holiday function was weakened and structurally transformed, and then 'frozen' as such for over 40 years.

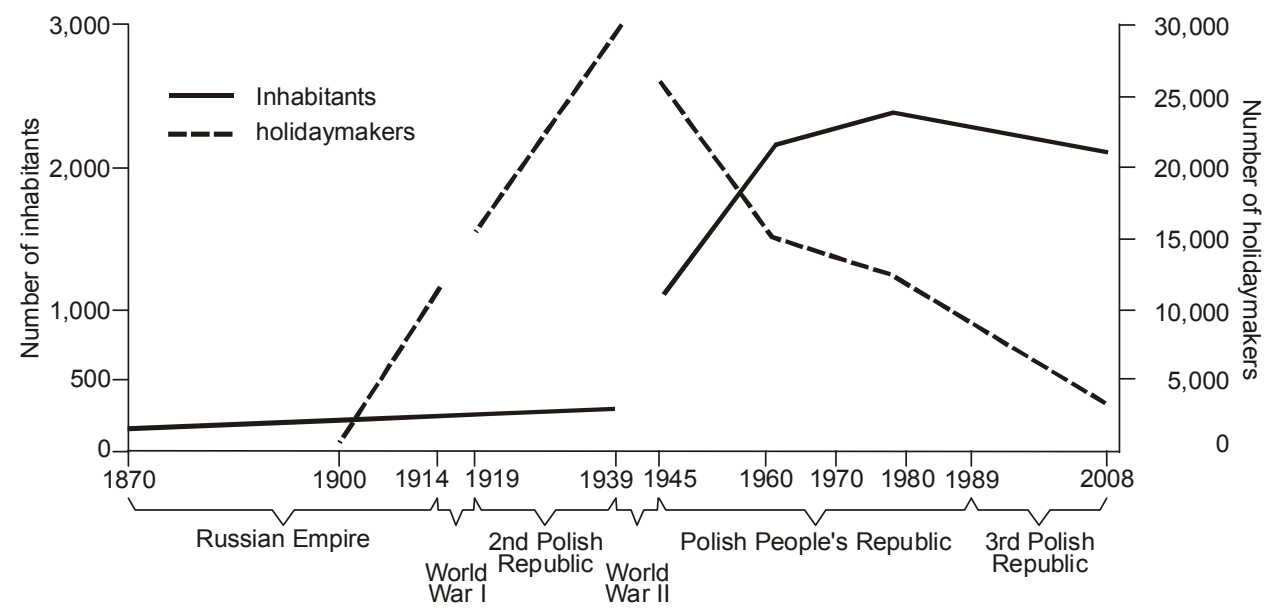

Fig. 2. Evolution of the residential function (number of permanent inhabitants) and recreational function (number of holidaymakers) of Wiśniowa Góra in 1870-2008; an illustration of the urbanization of a summer holiday estate

(s o u r c e: author)
The dynamic development of the dormitory function did not displace the holiday one completely, however it was considerably weakened and structurally transformed as part of the centrally planned economy in Poland after World War II. During the period of the Polish People's Republic the holiday function was strongly rivalled by the development of organized workers' and family holidays lasting a fortnight at the most attractive tourist destinations of Poland, especially at the seaside and in the mountains, subsidized by the state. This resulted in a considerable decrease in the number of holidaymakers coming to the less attractive Wiś-
In the 1970s and 1980s the development was relatively slow and the holiday function clearly stagnated, despite some investments in modernization (e.g. the Relaks Sport and Recreation Centre). In the early 1980s, about 12000 people spent their holidays there, mainly the inhabitants of Łódź and its conurbation, but nearly $15 \%$ came from outside the city and its region. Wiśniowa Góra had a limited holiday function locally, focused on weekend recreation. On the other hand, the development of the dormitory function slowed down considerably after 1960. National censuses from 1960-88 show that the population did not increase by more than 300 people 
on the other hand construction activity was quite intensive and almost $1 / 4$ of today's buildings come from that period. They were mainly brick, one- or two-storey houses usually equipped with the basic conveniences such as the bathroom, WC and hot water and after 1989 many were upgraded with more modern conveniences. In the 1970s and 1980s Łódź still remained the workplace for the inhabitants of Wiśniowa Góra.

In the second half of the 1980s, especially after 1989, when Poland returned to a market economy, and the whole economic and political system was transformed, the holiday function clearly declined. Summer centres for children, until then subsidized by Łodź factories (enterprises) were closed down and this resulted in a radical decrease in the number of holidaymakers, both children and their parents who visited them at the weekends with the only centre remaining Relaks, which is still operating and providing tourist and recreation services. In the mid-1990s it served about 3500 guests annually, the majority of whom were travellers seeking cheap accommodation to spend the night, both Poles and foreigners (mostly from behind the eastern border). They were not Łódź inhabitants coming for a longer holiday and at present, the number and type of guests remains more or less the same. Since the war, the number of individual plots has remained mostly unchanged (about 50). Their owners are nearly exclusively Łódź inhabitants, over 40 , with secondary or university education, professionals and technicians. Nearly $1 / 3$ of the plot owners are already retired and stay from May to September with their immediate family. Most summer houses were built in the 1990s and Łódź inhabitants are becoming increasingly interested in Wiśniowa Góra as a residential estate. As a result, residential building has been flourishing there since 1989 and the field study conducted in 2004 shows that nearly a fifth were built after 1989. They are nearly exclusively brick, one- and two-storey houses with a larger number of rooms (on average 4-6), well-equipped with the basic modern conveniences such as a bathroom, WC, hot water etc. Together with the modernization of old residential buildings, mentioned earlier, almost half of the present housing resources come up to the standards of a modern, well equipped, one-family residential building, typical of such areas populated by well-off inhabitants. In such a place you spend the night rather than the day and currently it provides employment for less than $10 \%$ of its working population. The main place of work, study and shopping being the centre of Łódź, together with its peripheral eastern districts, as well as the gmina centre of Andrespol.

At present, Wiśniowa Góra is transforming itself into a suburb situated on the eastern administrative border of Łodź, mostly due to favourable natural conditions, the close proximity and easy accessibility from Łódź, as well as the good reputation it has enjoyed locally and within the wider conurbation since the interwar period. As a result many affluent families from Łódź are interested in buying a plot of land there and in building a house. In this way the former holiday estate is being urbanized and its holiday function is being shifted to the other, less popular places and to more distant rural areas.

Translated by Ewa Mossakowska

\section{BIBLIOGRAFIA}

MATCZAK A., 1982, Funkcja wypoczynkowa strefy podmiejskiej Łodzi, Doctor's disertation, at the Łódź University, Łódź.

PRYC B., 1962, Wiśniowa Góra, Master's thesis at the Institute of Urban Geography and Tourism, Łódź University, Łódź.

WILCZAK G., 1984, Funkcja wypoczynkowa osiedla Wiśniowa Góra, Master's thesis at the Institute of Urban Geography and Tourism, Łódź University, Łódź.

MATCZAK A., 2005, Rozwój podmiejskich osiedli letniskowych w świetle koncepcji cyklu życia obszaru turystycznego. Przykład podłódzkiego letniska w Wiśniowej Górze, [w:] Geografia i sakrum, B. Domański i S. Skiba (ed.), vol. 2, pp. 115-122. 